\title{
SOFC INTERCONNECT DEVELOPMENT
}

Final Report

3/9/03

$12 / 9 / 04$

Diane M. England, Ph.D.

March 16, 2004

DOE Award Number (DE-FC26-01NT41022)

Delphi Corporation

5500 West Henrietta Road

West Henrietta, NY 14469

(585) 359-6661

diane.england@delphi.com

Lane Wilson

(304) 285-1336

lane.wilson@netl.doe.gov 


\section{DISCLAIMER}

"This report was prepared as an account of work sponsored by an agency of the United States Government. Neither the United States Government nor any agency thereof, nor any of their employees, makes any warranty, express or implied, or assumes any legal liability or responsibility for the accuracy, completeness, or usefulness of any information, apparatus, product, or process disclosed, or represents that its use would not infringe privately owned rights. Reference herein to any specific commercial product, process, or service by trade name, trademark, manufacturer, or otherwise does not necessarily constitute or imply its endorsement, recommendation, or favoring by the United States Government or any agency thereof. The views and opinions authors expressed herein do not necessarily state or reflect those of the United States Government or any agency thereof." 


\begin{abstract}
An interconnect for an SOFC stack is used to connect fuel cells into a stack. SOFC stacks are expected to run for 40,000 hours and 10 thermal cycles for the stationary application and 10,000 hours and 7000 thermal cycles for the transportation application. The interconnect of a stack must be economical and robust enough to survive the SOFC stack operation temperature of $750^{\circ} \mathrm{C}$ and must maintain the electrical connection to the fuel cells throughout the lifetime and under thermal cycling conditions. Ferritic and austenitic stainless steels, and nickel-based superalloys were investigated as possible interconnect materials for solid oxide fuel cell (SOFC) stacks. The alloys were thermally cycled in air and in a wet nitrogen-argon-hydrogen $\left(\mathrm{N}_{2}\right.$-Ar$\mathrm{H}_{2}-\mathrm{H}_{2} \mathrm{O}$ ) atmosphere. Thermogravimetry was used to determine the parabolic oxidation rate constants of the alloys in both atmospheres. The area-specific resistance of the oxide scale and metal substrates were measured using a two-probe technique with platinum contacts. The study identifies two new interconnect designs which can be used with both bonded and compressive stack sealing mechanisms. The new interconnect designs offer a solution to chromium vaporization, which can lead to degradation of some (chromium-sensitive) SOFC cathodes.
\end{abstract}

\title{
TABLE OF CONTENTS
}

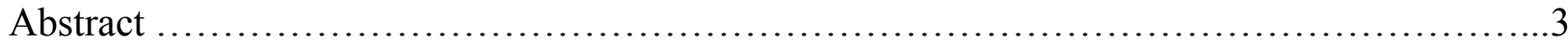

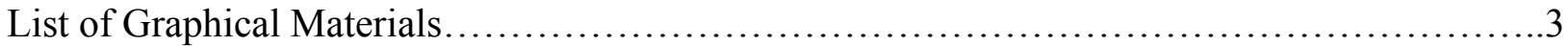

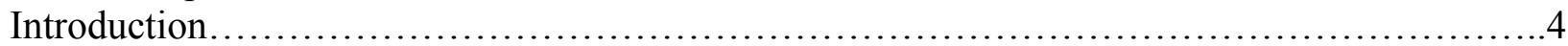

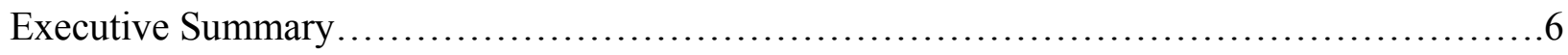

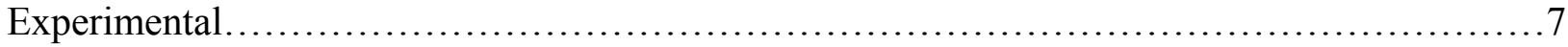

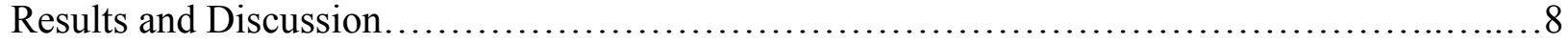

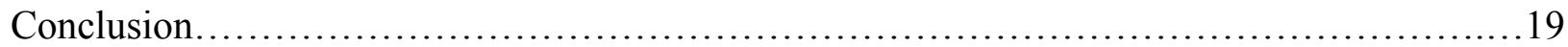

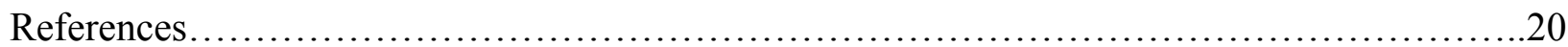

\section{LIST OF GRAPHICAL MATERIALS}

Figure 1 (Weight change/area) ${ }^{2}$ vs. time for samples oxidized in air at $750^{\circ} \mathrm{C} \ldots \ldots \ldots \ldots \ldots . . . . .9$

Figure 2 Comparison of (weight change/area) ${ }^{2}$ vs. oxidation time for coated and uncoated samples oxidized in air at $750^{\circ} \mathrm{C}$.

Figure 3 (Weight change/area) ${ }^{2}$ vs. oxidation time for samples oxidized in $\mathrm{N}_{2}-\mathrm{Ar}_{-}-\mathrm{H}_{2}-\mathrm{H}_{2} \mathrm{O}$

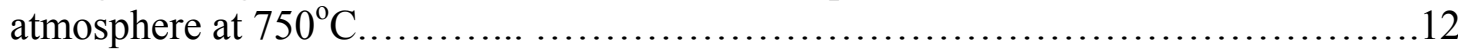

Figure 4 Comparison of the area-specific resistance vs. 1000/temperature for the LSC and Manganese chromium oxide coated 430Ti and 302SS alloy samples after 500 hours of oxidation at $750^{\circ} \mathrm{C}$ in air under thermal cycling conditions.

\section{(3)}

\author{
7
}

19

0


Figure 8 Shows insertable via interconnect design as a solid geometry. Outer (purple) portion is made of a ferritic stainless steel. Inner (blue) portion is made of a Ni-based superalloy....

Figure 9 Insertable via interconnect design as an exploded line drawing. Outer (purple) portion is made of a ferritic stainless steel. Inner (blue) portion is made of a Ni-based

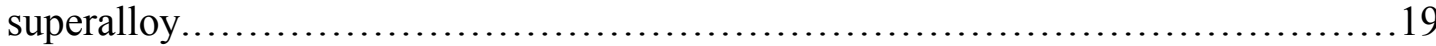

Table 1 Parabolic rate constants for alloys oxidized in air at $750^{\circ} \mathrm{C} \ldots \ldots \ldots \ldots \ldots \ldots \ldots \ldots \ldots \ldots \ldots$

Table 2 Parabolic rate constants for alloys oxidized in $\mathrm{N}_{2}-\mathrm{Ar}-\mathrm{H}_{2}-\mathrm{H}_{2} \mathrm{O}$ at $750^{\circ} \mathrm{C} \ldots \ldots \ldots \ldots \ldots . . . .12$

Table 3 The thickness of the LSC coating on the alloys......................................................14

\section{INTRODUCTION}

The oxidation of metals is an important subject for the application of metals in high temperature environments such as an interconnect for an SOFC stack. The interconnect must perform for 40,000 hours and 10 thermal cycles for the stationary application and 10,000 hours and 7000 thermal cycles for the transportation application. The suitability of a variety of Ni-based superalloys, ferritic stainless steels and austenitic stainless steels were selected for this study. Coatings were investigated to decrease the electrical resistance of the interconnect and to decrease the diffusion of $\mathrm{Cr}$ to the surface where it could vaporize which may adversely affect some cathodes sensitive to chromium degradation. Thermogravimetric measurements were used to determine the oxidation rate of these alloys. A two-probe resistance measurement was used to determine the area-specific resistance of the oxide scale layers which have not spalled. It must be noted here that the task of the interconnect is to electrically connect the fuel cells in series. Spalling of the oxide scale from its metallic substrate would result in the electrical disconnection of the SOFC stack. Hence, spalling of the oxide scale formed on a metallic interconnect must be considered to severely and negatively influence the performance of the SOFC stack. Further, a two-probe resistance measurement will also measure the contact resistance

\section{Interconnect Requirements}

The interconnect must electrically and physically connect the fuel cells in the stack in electrical series. The interconnect prevents mixing of the anode and cathode gases which would result in the uncontrollable combustion of the gases. A metallic interconnect of an SOFC must have the following requirements.

1. It must have excellent electrical conductivity including the oxide scales which form in both air and fuel atmospheres.

2. It must be oxidation resistant in both air and fuel gases. The fuel gas includes hydrogen, carbon monoxide, water vapor, carbon dioxide, and small quantities of methane.

3. It must be impermeable to both the fuel and air gases.

4. The oxide scale formed must be strongly adhered to the alloy substrate and remain strongly adhered during multiple thermal cycles. Spalling of the oxide scale would result in the electrical disconnection of the fuel cells in the SOFC stack.

5. It must be flexible enough to withstand thermal expansion mismatches or match the thermal expansion coefficient of the fuel cell components.

6. It must withstand repeated thermal cycling from room temperature to $800^{\circ} \mathrm{C}$. 
7. It must be inexpensive. The interconnect parts must be less than $\$ 1.00 /$ each including manufacturing and materials.

8. The material must allow high volume manufacturing. 


\section{EXECUTIVE SUMMARY}

Solid oxide fuel cells convert hydrogen and fossil fuels into electricity. The interconnect electrically connects individual fuel cells serially in a stack. The interconnect connects the anode of one fuel cell with the cathode of an adjacent fuel cell in the fuel cell stack. Series operation allows the attainment of higher voltages, which is necessary for use in both mobile and stationary applications. The interconnect has certain requirements that it must meet. The interconnect material must be highly thermally conductive to prevent thermal temperature gradients in the SOFC stack. The interconnect must separate the anode and cathodes gases from mixing. If the anode and cathode gases mix, spontaneous combustion will occur which will lead to thermal temperature gradients within the stack. Thermal temperature gradients in the stack must be minimized to prevent cracking of the SOFC stack. Cracking occurs because ceramic fuel cells cannot withstand the stresses induced by highly localized thermal temperature gradients. The interconnect material must be physically and chemically stable in the operating environments of the fuel cell stack. Hence, the material must not catastrophically oxidize or corrode during operation of the SOFC stack. The interconnect material must be impermeable to both the anode and cathode gases to prevent leakage current and loss of efficiency of the SOFC stack. The interconnect material must remain electrically conductive in both the cathode and anode gases under thermal cycling conditions lifetime of the stack which can be as much as 40,000 hours. If an oxide scale forms on the interconnect during operation then the oxide scale must also be electronically conductive and remain adhered to the substrate. Any spalling of the oxide scale from the substrate represents an electrical disconnection of the interconnect from the cathode or anode. Each disconnection causes an increase in resistance until overall failure of the SOFC stack occurs.

The metallic alloys are candidate materials for the interconnect of an SOFC stack. Metallic interconnects have an economic advantage over ceramic interconnects. The interconnects must be less than $\$ 1.00$ each, which includes all manufacturing costs. The economics of the interconnect do not allow the use of precious metals (platinum, gold, etc...), as well as, exotically expensive alloys such as alumina-forming alloys and oxide-dispersion strengthened (ODS) alloys. Therefore, Ni-based superalloys, ferritic and austenitic stainless steels are acceptable in terms of economics for use as materials in an SOFC stacks.

Delphi has two power applications. A stationary application which is expected to operate for 40,000 hours and 10 thermal cycles and a transportation application which is expected to operate for 10,000 hours and 7000 thermal cycles. This interconnect project investigated the oxidation kinetics and area-specific resistance of coated and uncoated alloys for use as interconnect materials for an SOFC stack. A coating which suppresses the diffusion of chromium and significantly decreases the area-specific resistance of the interconnect was identified, as well as, a coating process which optimizes this performance. Two new interconnect designs were created which can be used with either compressive or bonded sealing stack mechanisms. 


\section{EXPERIMENTAL}

\section{Sample Preparation}

The materials selected for this study included ferritic stainless steels, austenitic stainless steels, and Ni-based superalloys. The ferritic stainless steels were chosen for the lower coefficients of thermal expansion of this class of alloys. The ferritic stainless steels were chosen for the closer coefficient of thermal expansion (CTE) match to glass sealing materials used in the Delphi SOFC stack. The problem with ferritic stainless steels is the fast oxidation kinetics at temperatures above $650^{\circ} \mathrm{C}$. The austenitic stainless steel was chosen because of the slower oxidation kinetics exhibited by this type of alloy compared to ferritic stainless steels at the operation temperature of an SOFC stack. The maximum use temperature of austenitic stainless steels is $750^{\circ} \mathrm{C}$. The Ni-based superalloys were chosen for the consistent performance in terms of acceptable oxidation kinetics at the operating temperatures of SOFC stacks.

Coupons of the above alloys were prepared by a waterjet (abrasive) cutting method. The coupons were cleaned and the surface was prepared for coating according to the procedures established for each coating process at Delphi. Coatings were applied by screen-printing and collodial spray methods. The coatings applied were a manganese chromium oxide, strontiumdoped lanthanum cobaltite (LSC) and metallic silver.

The particle sizes of the powders were

$$
\begin{array}{ll}
\text { - } \mathrm{LSC} & \mathrm{d}_{10}=0.4 \mu \mathrm{m}, \mathrm{d}_{50}=0.6 \mu \mathrm{m}, \mathrm{d}_{95}=0.9 \mu \mathrm{m} \\
\text { - } \mathrm{MnCr} & \mathrm{d}_{10}=0.6 \mu \mathrm{m}, \mathrm{d}_{50}=0.8 \mu \mathrm{m}, \mathrm{d}_{55}=2.9 \mu \mathrm{m}
\end{array}
$$

Colloidal spray

The spray was formulated by ball milling the constituents in IPA. We then used a gravity-fed Brinks spray pot to apply a room temperature colloidal spray. The samples were air dried and laser scanned for thickness.

Screen print

The pastes were formulated by 3 roll milling the constituents in a Ferro BD75717 vehicle. These pastes were then applied with a TF-100 screen printer. The samples were dried at $70^{\circ} \mathrm{C}$ for 20 minutes and then laser scanned for thickness.

The samples oxidized in air were oxidized at $750^{\circ} \mathrm{C}$ under thermal cycling conditions in air, $\mathrm{pO}_{2}=0.21 \mathrm{~atm}$. The thermal cycling condition was to heat the coupons from ambient to $750^{\circ} \mathrm{C}$ at $15^{\circ} \mathrm{C} /$ minute in a furnace. The furnace temperature was maintained at $750^{\circ} \mathrm{C}$ for the oxidation times reported. The time for heat up and cool down were not included in the oxidation times reported.

The samples oxidized in an $\mathrm{N}_{2}-\mathrm{Ar}-\mathrm{H}_{2}-\mathrm{H}_{2} \mathrm{O}$ atmosphere were oxidized at $750^{\circ} \mathrm{C}$ under thermal cycling conditions. The $20 \%$ hydrogen-argon gas mixture was bubbled through water, $\mathrm{T}_{\text {bubbler }}=80^{\circ} \mathrm{C}$, to fix the $\mathrm{p}_{\mathrm{H}_{2} \mathrm{O}}$ at $0.472 \mathrm{~atm}$ prior to passing it through the furnace. The samples were oxidized at $750^{\circ} \mathrm{C}$. The $\mathrm{p}_{\mathrm{O}_{2}}$ in the wet hydrogen atmosphere was determined using the equations, 
$\log \left(\mathrm{p}_{\mathrm{H}_{2} \mathrm{O}}\right)=\frac{-2961}{\mathrm{~T}_{\text {Bubbler }}}-5.13 \log \left(\mathrm{T}_{\text {Bubbler }}\right)+21.133$ and $\mathrm{p}_{\mathrm{O}_{2}}=\left(\frac{\mathrm{p}_{\mathrm{H}_{2} \mathrm{O}}}{\mathrm{p}_{\mathrm{H}_{2}}}\right)^{2} \exp \left(\frac{-246000+54.8 \mathrm{~T}}{8.3144 \mathrm{~T}}\right)^{2}$,

with $\mathrm{p}_{\mathrm{H}_{2}} \approx 0.2 \mathrm{~atm}$. The partial pressure of oxygen was determined to be on the order of $5.6 \times 10^{-18} \mathrm{~atm}$. The thermal cycling condition was to heat the coupons from ambient to $750^{\circ} \mathrm{C}$ at $8^{\circ} \mathrm{C} /$ minute in a retort furnace. The furnace temperature was maintained at $750^{\circ} \mathrm{C}$ for the oxidation times reported. The time for heat up and cool down were not included in the oxidation times reported.

\section{RESULTS AND DISCUSSION}

\section{Oxidation in Air for Uncoated Samples}

Figure 1 shows a comparison of all the alloys oxidized in air at $750^{\circ} \mathrm{C}$ in this study. The nickel-based (Ni-based) alloys exhibited significantly slower oxidation kinetics than the ironbased (Fe-based) alloys. The Haynes 230 alloy had the slowest growing oxide scale. The stainless steel (SS) 439 had the fastest growing oxide scale until 1192 hours of oxidation was reached, after which it spalled its oxide scale. After 1192 hours of oxidation Crofer 22 APU became the alloy with the fastest growing oxide scale, which still maintained adherence of the oxide scale to the metallic substrate. However, Crofer 22 did lightly spall its oxide scale after 2800 hours, which is the reason for the change in slope observed in Figure 1 for this alloy. The parabolic rate constants for the alloys oxidized in air at $750^{\circ} \mathrm{C}$, which were determined by thermogravimetry, are tabulated in Table 1. A parabolic rate constant for 409SS could not be determined due to lack of fit of the data. The lack of fit was the result of extreme spalling of its oxide scale from the substrate. A previous study determined the parabolic rate constant of Haynes 230 at $800^{\circ} \mathrm{C}$ in air to be $\mathrm{kg}_{\mathrm{g}}=4 \times 10^{-12} \mathrm{~g}^{2} / \mathrm{cm}^{4}$-hour. ${ }^{1}$ Since it is expected that the oxidation rate of these alloys will decrease with a decrease in temperature, it is a good fit to the present parabolic rate constant for Haynes $230, \mathrm{~kg}_{\mathrm{g}}=1 \times 10^{-13} \mathrm{~g}^{2} / \mathrm{cm}^{4}$-hour at $750^{\circ} \mathrm{C}$.

\section{Oxidation in Air for Coated Samples}

Figure 2 is a comparison of the (weight change/area) ${ }^{2}$ vs. oxidation time for coated and uncoated samples oxidized in air at $750^{\circ} \mathrm{C}$. Figure 2 shows that the oxidation kinetics of the coated alloys increased compared to the uncoated alloys. The oxidation rate increase may be the result of the coating, surface preparation techniques, solvents used in the coating process or some combination of any of these conditions. The LSC-coated samples exhibited the smallest oxidation rate increase compared to their uncoated counterparts and the silver-coated samples exhibited the largest oxidation rate increase. 


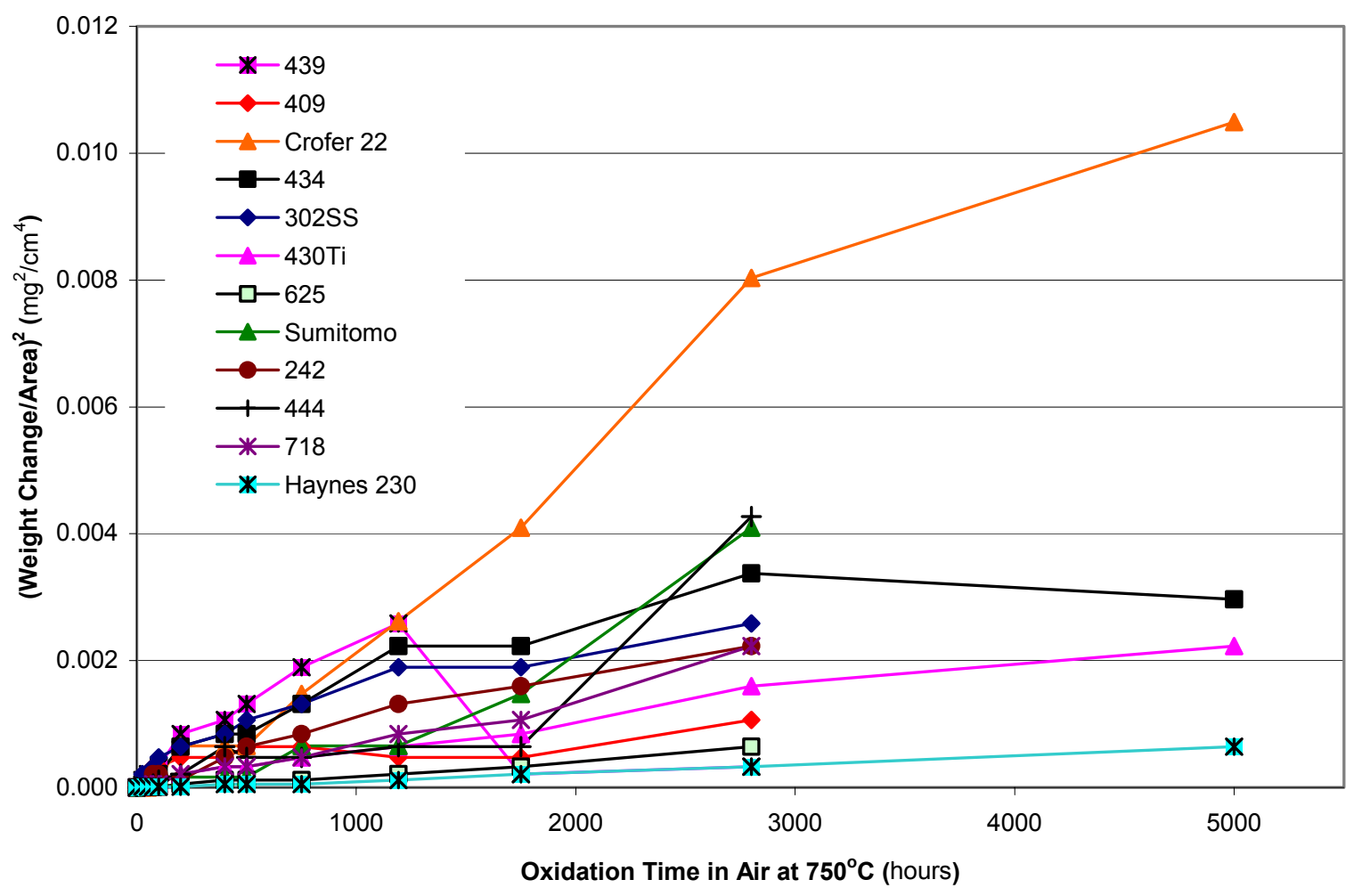

Figure 1. (Weight change/area) $)^{2}$ vs. time for samples oxidized in air at $750^{\circ} \mathrm{C}$. 


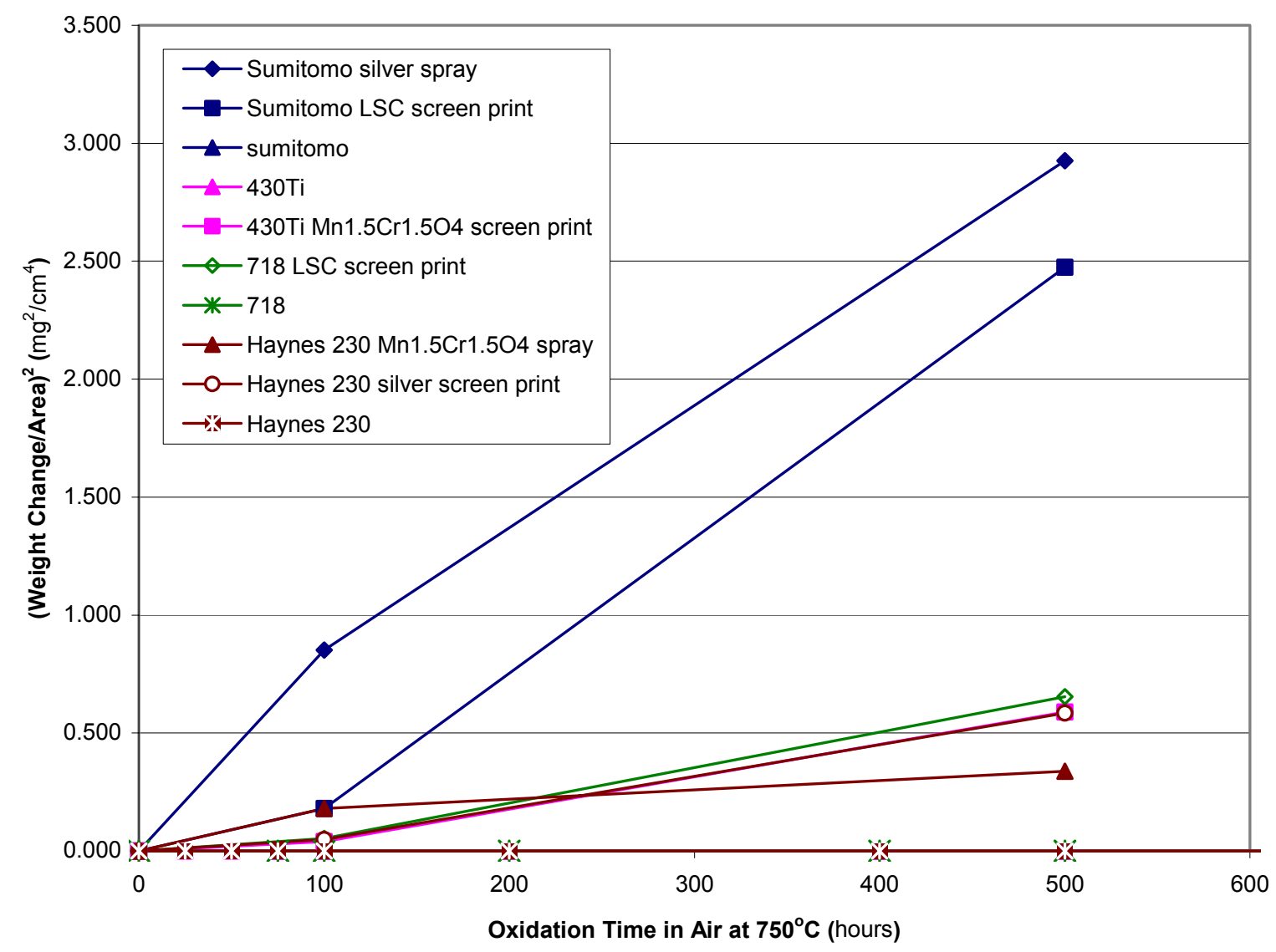

Figure 2. Comparison of (weight change/area) ${ }^{2}$ vs. oxidation time for coated and uncoated samples oxidized in air at $750^{\circ} \mathrm{C}$.

\section{Oxidation in Wet Nitrogen-Hydrogen Atmosphere}

A wet nitrogen-argon-hydrogen atmosphere $\left(\mathrm{N}_{2}-\mathrm{Ar}-\mathrm{H}_{2}-\mathrm{H}_{2} \mathrm{O}\right)$ was used to simulate the fuel atmosphere on the anode side of a solid oxide fuel cell. Figure 3 shows the (weight change/area) ${ }^{2}$ of all the alloys oxidized in a $\mathrm{N}_{2}-\mathrm{Ar}-\mathrm{H}_{2}-\mathrm{H}_{2} \mathrm{O}$ atmosphere. Figure 3 indicates that Haynes 230 had the slowest oxidation kinetics in the $\mathrm{N}_{2}-\mathrm{Ar}-\mathrm{H}_{2}-\mathrm{H}_{2} \mathrm{O}$ atmosphere oxidation at $750^{\circ} \mathrm{C}$ under thermal cycling conditions. The figure also indicates that $439 \mathrm{SS}$ had the fastest oxidation kinetics of the alloys tested are tabulated in Table 2. The parabolic rate constants for the alloys oxidized in the $\mathrm{N}_{2}-\mathrm{Ar}-\mathrm{H}_{2}-\mathrm{H}_{2} \mathrm{O}$ atmosphere. The parabolic rate constants for oxidation in a simulated-fuel atmosphere are in good agreement with a previous study under similar conditions. ${ }^{2}$ Previous work found that the parabolic rate constant of Inconel 718 was $\mathrm{k}_{\mathrm{g}}=$ $1.01 \times 10^{-10} \mathrm{~g}^{2} / \mathrm{cm}^{4}$-hour ${ }^{2}$ which compares well with the parabolic rate constant determined in this study of $\mathrm{kg}_{\mathrm{g}}=1.50 \times 10^{-10} \mathrm{~g}^{2} / \mathrm{cm}^{4}$-hour. A comparison of the parabolic rate constants for these two atmospheric conditions shows that oxidation in a $\mathrm{N}_{2}-\mathrm{Ar}-\mathrm{H}_{2}-\mathrm{H}_{2} \mathrm{O}$ atmosphere is faster than in air. This result is consistent with previous work. ${ }^{3}$ The literature has many examples in which the oxidation in a low $\mathrm{pO}_{2}$ atmosphere was smaller than those in air. However, these studies were done at higher temperatures $\left(1100^{\circ} \mathrm{C}\right)$. The previous work also showed this difference in 
oxidation kinetics from an air to a low $\mathrm{pO}_{2}$ atmosphere at $1100^{\circ} \mathrm{C}$ but a crossover in oxidation occurs as temperature decreases. The crossover temperature is different for different alloys. ${ }^{3}$

\begin{tabular}{|c|c|}
\hline \multicolumn{2}{|c|}{$\begin{array}{c}\text { Comparison of Parabolic Rate Constants } \\
\mathrm{k}_{\mathrm{g}} \\
\text { (thermogravimetry) } \\
\text { in Air at } 750^{\circ} \mathrm{C}\end{array}$} \\
\hline Alloy & $\mathrm{g}^{2} / \mathrm{cm}^{4}$-hour \\
\hline $302 \mathrm{SS}$ & $1.29 \times 10^{-12}$ \\
$430 \mathrm{Ti}$ & $5.42 \times 10^{-13}$ \\
439 & $2.37 \times 10^{-12}$ \\
Haynes 230 & $1.23 \times 10^{-13}$ \\
434 & $1.58 \times 10^{-12}$ \\
Crofer 22 & $3.72 \times 10^{-12}$ \\
Sumitomo & $1.11 \times 10^{-12}$ \\
718 & $5.75 \times 10^{-13}$ \\
444 & $7.57 \times 10^{-13}$ \\
625 & $1.54 \times 10^{-13}$ \\
409 & ----- \\
\hline
\end{tabular}

Table 1. Parabolic rate constants for alloys oxidized in air at $750^{\circ} \mathrm{C}$. 


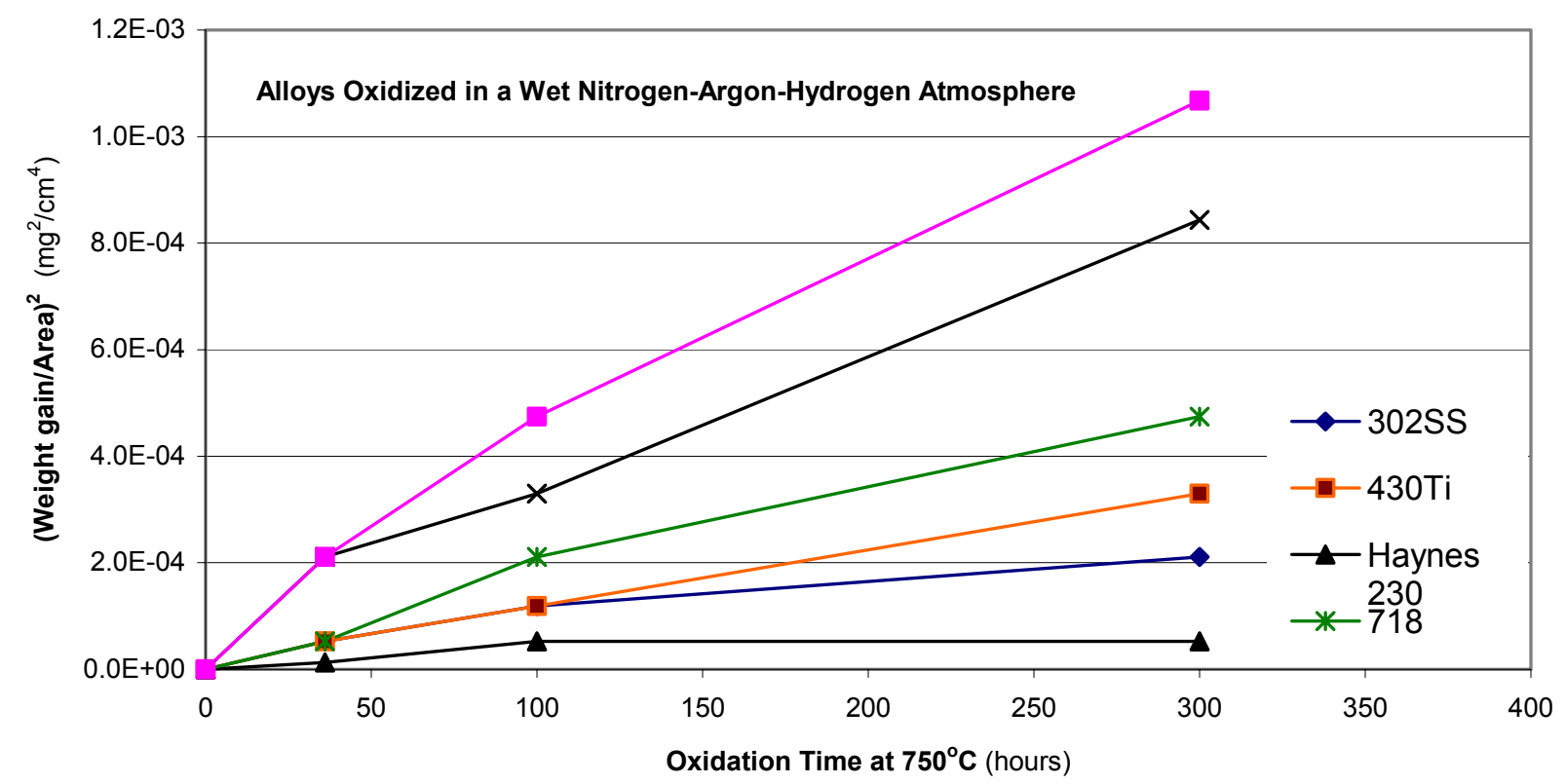

Figure 3. (Weight change/area) ${ }^{2}$ vs. oxidation time for samples oxidized in $\mathrm{N}_{2}-\mathrm{Ar}_{-}-\mathrm{H}_{2}-\mathrm{H}_{2} \mathrm{O}$ atmosphere at $750^{\circ} \mathrm{C}$.

\begin{tabular}{|c|c|}
\hline \multicolumn{2}{|c|}{$\begin{array}{c}\text { Comparison of Parabolic Rate Constants } \\
\qquad \mathrm{kg}_{\mathrm{g}} \\
\text { (thermogravimetry) } \\
\text { in } \mathrm{N}_{2}-\mathrm{H}_{2}-\mathrm{H}_{2} \mathrm{O} \text { at } 750^{\circ} \mathrm{C} \\
\end{array}$} \\
\hline Alloy & $\mathrm{g}^{2} / \mathrm{cm}^{4}$-hour \\
\hline 430Ti & 9.17E-10 \\
\hline $\mathrm{H} 230$ & 2.87E-10 \\
\hline Crofer 22 & 2.20E-09 \\
\hline 302 & $6.00 \mathrm{E}-10$ \\
\hline 718 & 1.50E-09 \\
\hline
\end{tabular}

Table 2. Parabolic rate constants for alloys oxidized in $\mathrm{N}_{2}-\mathrm{Ar}-\mathrm{H}_{2}-\mathrm{H}_{2} \mathrm{O}$ at $750^{\circ} \mathrm{C}$. 


\section{Area-Specific Resistance Measurements}

Figure 4 compares the area-specific resistance vs. 1000/temperature for 430Ti and 302SS alloys after oxidation at $750^{\circ} \mathrm{C}$ for 500 hours. The graph shows that the samples coated with an LSCcoating exhibit a lower area-specific resistance than the subsequent alloys coated with a $\mathrm{Mn}, \mathrm{Cr}$ oxide coating. Figure 5 compares the area-specific resistance vs. 1000/temperature for the alloys coated with LSC by collodial spray and screen-printing coating processes. Inconel 718 and the Sumitomo alloy coated with LSC exhibited the smallest area-specific resistance of the samples. Previous work showed that Haynes 230 had the lowest area-specific resistance of all the Nibased superalloys, including Inconel 718 , tested in air $^{1}$ and in a wet hydrogen atmosphere. ${ }^{2}$ Therefore, it is reasonable to conclude that Haynes 230 coated with LSC by a screen-printing process would exhibit an even lower area-specific resistance than Inconel 718.

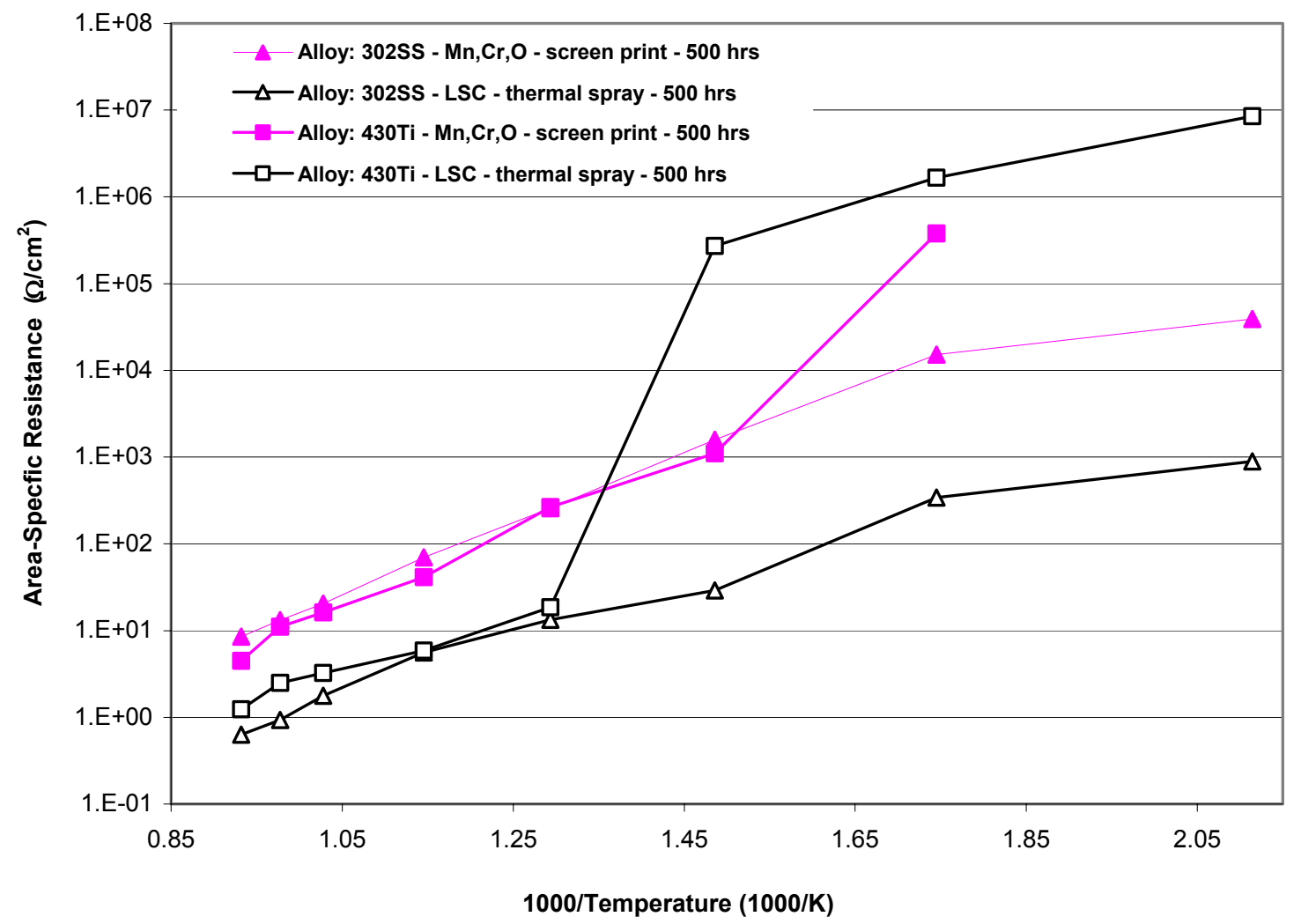

Figure 4. Comparison of the area-specific resistance vs. 1000/temperature for the LSC and Manganese chromium oxide coated 430Ti and 302SS alloy samples after 500 hours of oxidation at $750^{\circ} \mathrm{C}$ in air under thermal cycling conditions. 


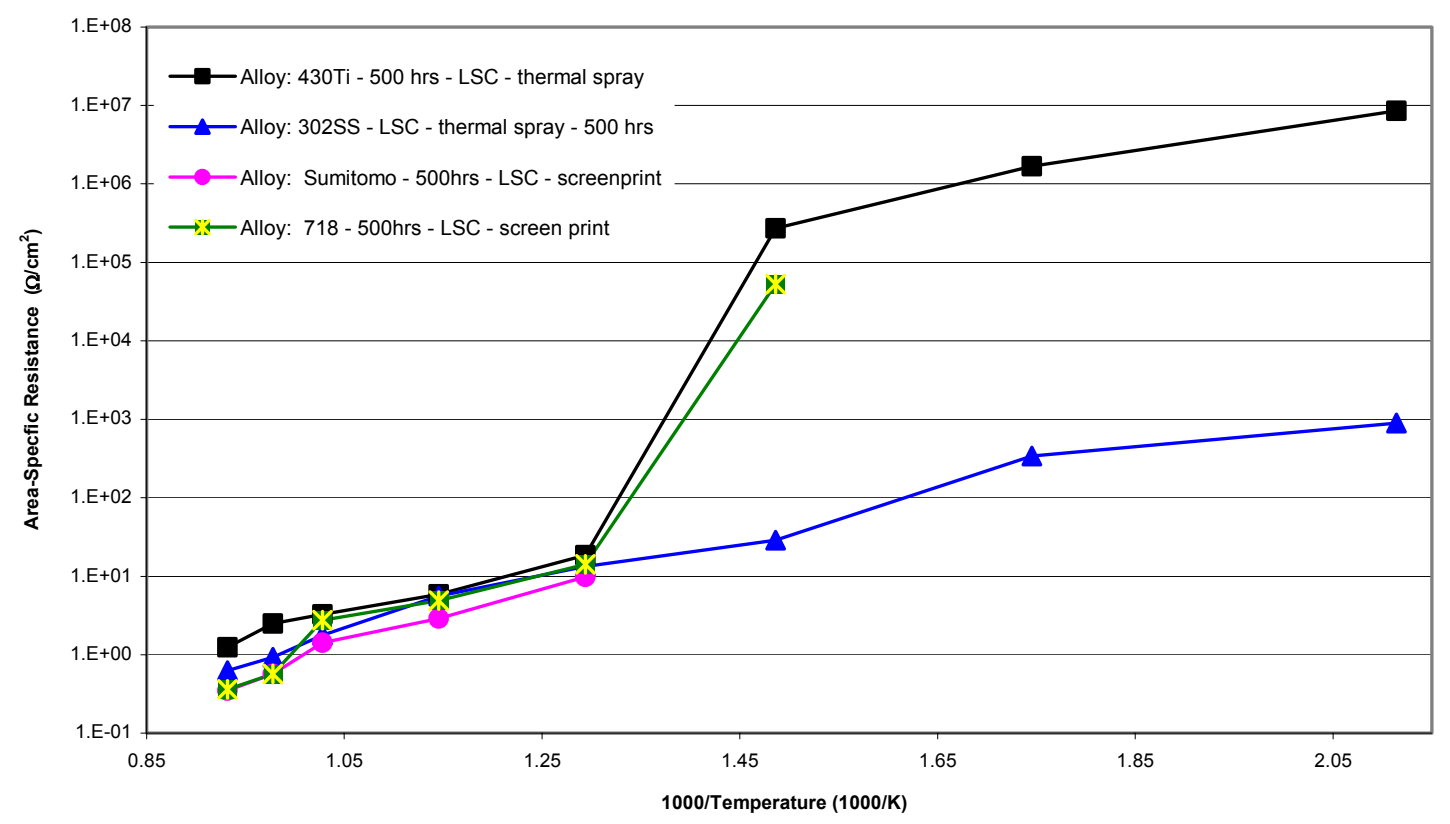

Figure 5. Comparison of the Area-specific resistance vs. 1000/temperature for the LSC-coated samples after 500 hours of oxidation at $750^{\circ} \mathrm{C}$ in air under thermal cycling conditions. The samples under went 10 thermal cycles from ambient to $750^{\circ} \mathrm{C}$ during the oxidation time.

\section{MICROSTRUCTURE}

Figure 6 is an energy dispersive spectrum of the LSC-coated, Inconel 718 substrate after 500 hours of oxidation in air. The figure shows that no chromium was detected in the coating. The EDS spectrums for the LSC-coated Sumitomo and 430Ti alloys indicated chromium was present in the coatings on those alloys after oxidation. Since the oxidation kinetics of Haynes 230 are slower than Inconel 718, the diffusion of chromium to the surface will be even slower for a substrate of Haynes 230. Figure 7 shows the thickness of the LSC coatings and processes on 718, Sumitomo, and 430Ti alloys.

\begin{tabular}{|c|c|c|}
\hline Alloy & Coating Process & Coating Thickness \\
\hline 718 & screen print & 15 \\
\hline $430 \mathrm{Ti}$ & spray & 19 \\
\hline Sumitomo & screen print & 11 \\
\hline
\end{tabular}

Table 3. The thickness of the LSC coating on the alloys. 


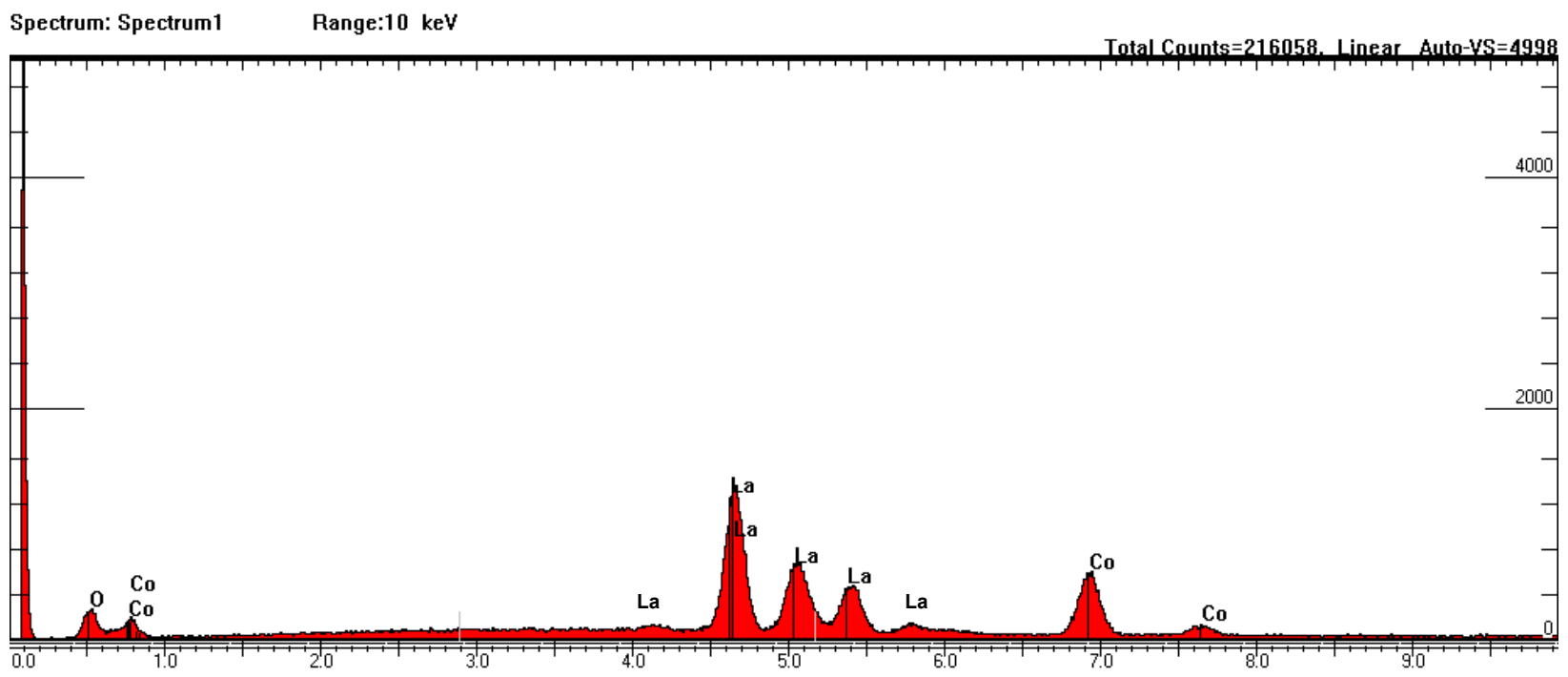

Figure 6. The EDS spectrum of the LSC-coated, Inconel 718 sample after 500 hours of oxidation at $750^{\circ} \mathrm{C}$ in air.

\section{NEW INTERCONNECT DESIGN}

Coatings can be used to improve the electrical resistance of the interconnect and to reduce the vaporization of the chromium from the base alloy. A previous study showed that the a Mncoating on the anode side of a Haynes 230 interconnect significantly reduce the electrical resistance of the interconnect in a fuel atmosphere. ${ }^{4}$ The current project shows that an LSCcoating on the cathode side of an interconnect made of Inconel 718 or Haynes 230 would significantly reduce the electrical resistance of the alloy and also suppressed the diffusion of chromium through the LSC coating to the surface. This makes it possible to use chromiaforming alloys even with cathodes which are sensitive to chromium contamination. Previous work found that the oxidation kinetics of Haynes 230 were significantly less than Inconel 718 in both air and wet hydrogen. ${ }^{1,2}$ Therefore, an LSC-coating on Haynes 230 should exhibit even less chromium diffusion through the coating. Further, the previous work also demonstrated that Haynes 230 was less resistive than Inconel 718 after oxidaiton in air. Hence, an interconnect made of Haynes 230 with an LSC-coating deposited by screen-printing on the cathode side and a Mn-coating deposited on the anode side of the interconnect would result in an interconnect with the lowest electrical resistance and lowest chromium evolution.

The alloy choice of an interconnect for an SOFC stack has been intimately tied to the type of sealing in the stack (compressive vs. bonded). The stack maufacturers using bonded seals must use alloys which have a close coefficient of thermal expansion (CTE) to the fuel cell and bonded seal components. This has generally resulted in the use of ferritic stainless steels for this type of sealed SOFC stack. The use of ferritic stainless steels at the operating temperature of an SOFC stack $\left(750^{\circ} \mathrm{C}\right)$ represents a severe corrosion problem. Ferritic stainless steels oxidize too quickly at temperatures above $650^{\circ} \mathrm{C}$ to be useful. Compressive sealing strategies allow the use of nickel-based superalloys which have significantly slower oxidation kinetics than the ferritic 
stainless steel alloys. Therefore, a compressive seal manufacturer can use the double-coated interconnect design. ${ }^{5}$

An insertable via interconnect design ${ }^{6}$ allows stack manufacturers using a bonded sealing mechanism to use Ni-based superalloys as the interconnect while still using ferritic stainless steels for connection to the bonded seals. Figure 7 shows the insertable via interconnect design. The outer part of the interconnect is a made of a ferritic stainless steel (430Ti, Crofer 22, etc...). This part of the interconnect is bonded with the sealing materials, such as ceramic glasses, reaction brazes, etc... The bonded sealing materials protect the ferritic stainless steels from the severe oxidation conditions seen by the inner part of the interconnect. The inner part of the interconnect is made of a Ni-based superalloy such as Haynes 230, Inconel 718, etc.... Haynes 230 is the best choice based on its oxidation kinetics and the electrical resistance of its oxide scale. The inner and outer parts of the interconnect are bonded with Nicrobraz 150 which does not contain silicon. Silicon is a known contaminant of SOFC electrode materials. The brazing of ferritic stainless steels to nickel-based superalloys is usually accomplished by the use of a compliant inner layer within the braze joint. The inner layer is a shim of pure nickel or copper which allows the braze joint to withstand the CTE mismatch between the ferritic SS and the Nibased superalloy. This ductile inner braze layer dramatically reduces the stress on the braze joint allowing for multiple thermal cycling of the braze joint as required by an SOFC stack

application. Figure 7 also shows the rounded lap seal which joins the inner and outer parts of the interconnect. This is an important feature of the design. The larger area of the rounded lap joint makes a far stronger joint than traditional straight lap joint braze seal. ${ }^{7}$ The Ni-based alloy center of this interconnect is coated with LSC on the cathode side and Mn on the anode side. Hence, this design allows bonded sealing stack manufacturers to use ferritic stainless steels and Ni-based superalloys to get the best of both in an interconnect design. 


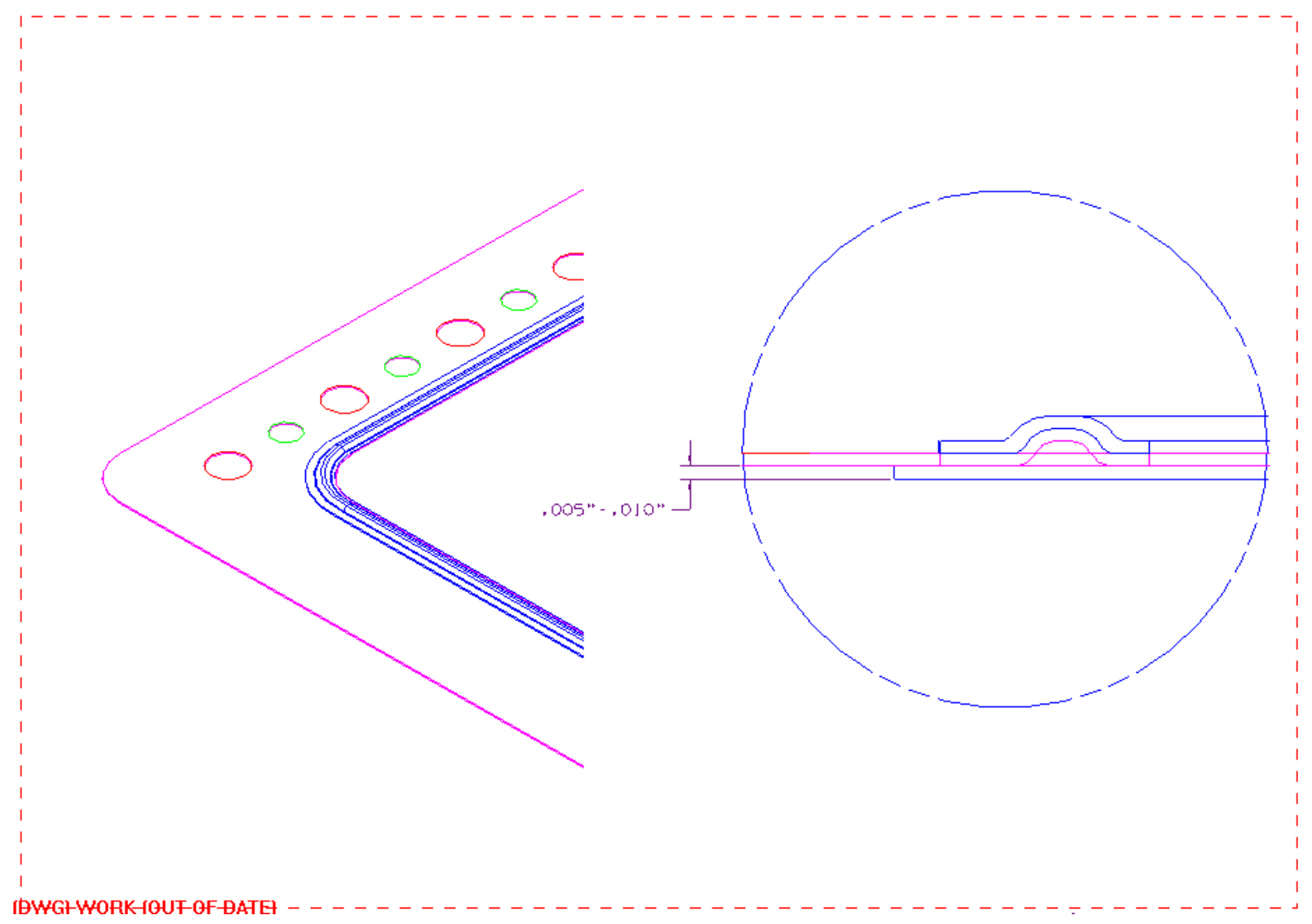

Figure 7. View of rounded lap braze joint. Circular inset illustrates cross-sectional geometry of the rounded lap braze joint. 


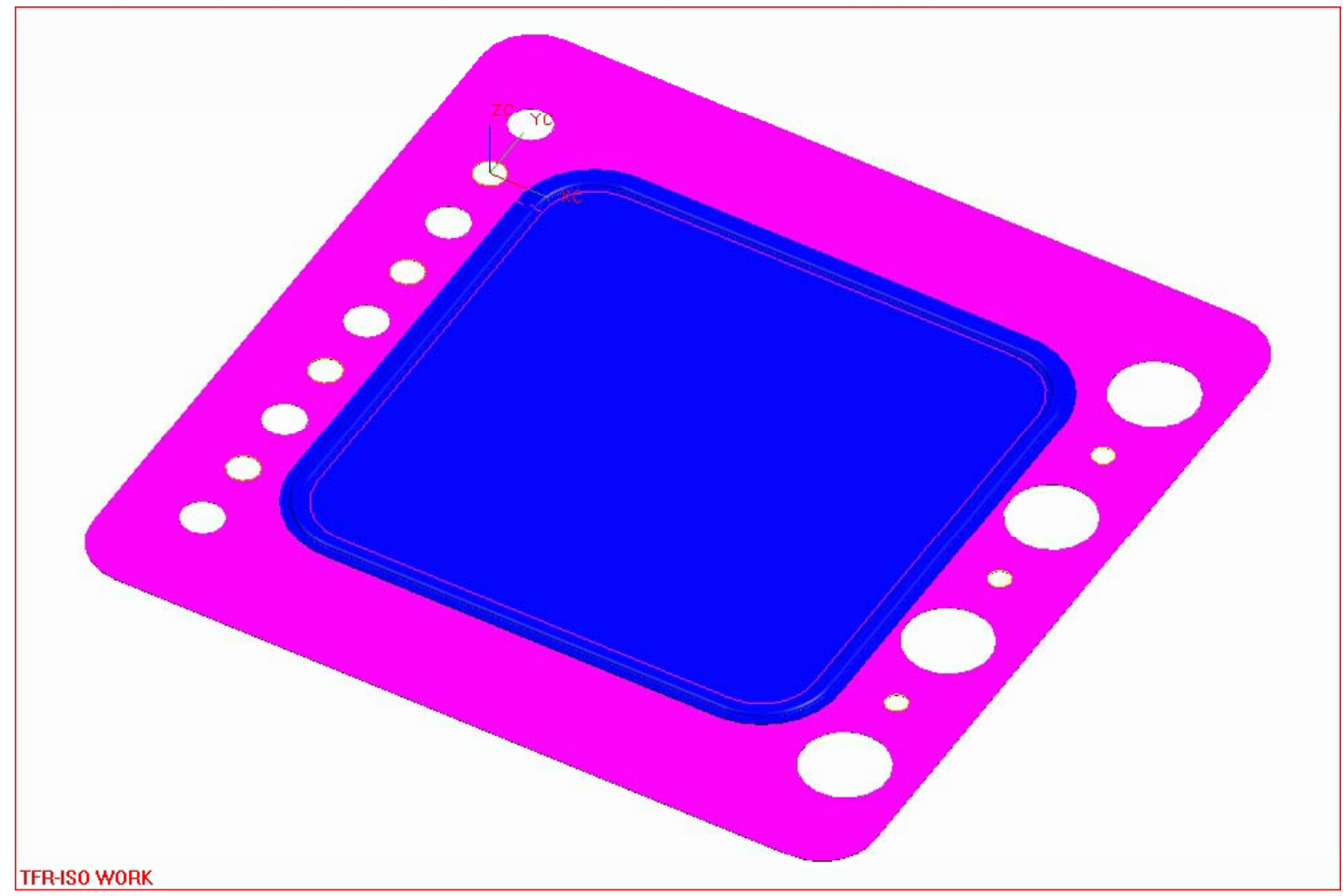

Figure 8. Shows insertable via interconnect design as a solid geometry. Outer (purple) portion is made of a ferritic stainless steel. Inner (blue) portion is made of a Ni-based superalloy. 


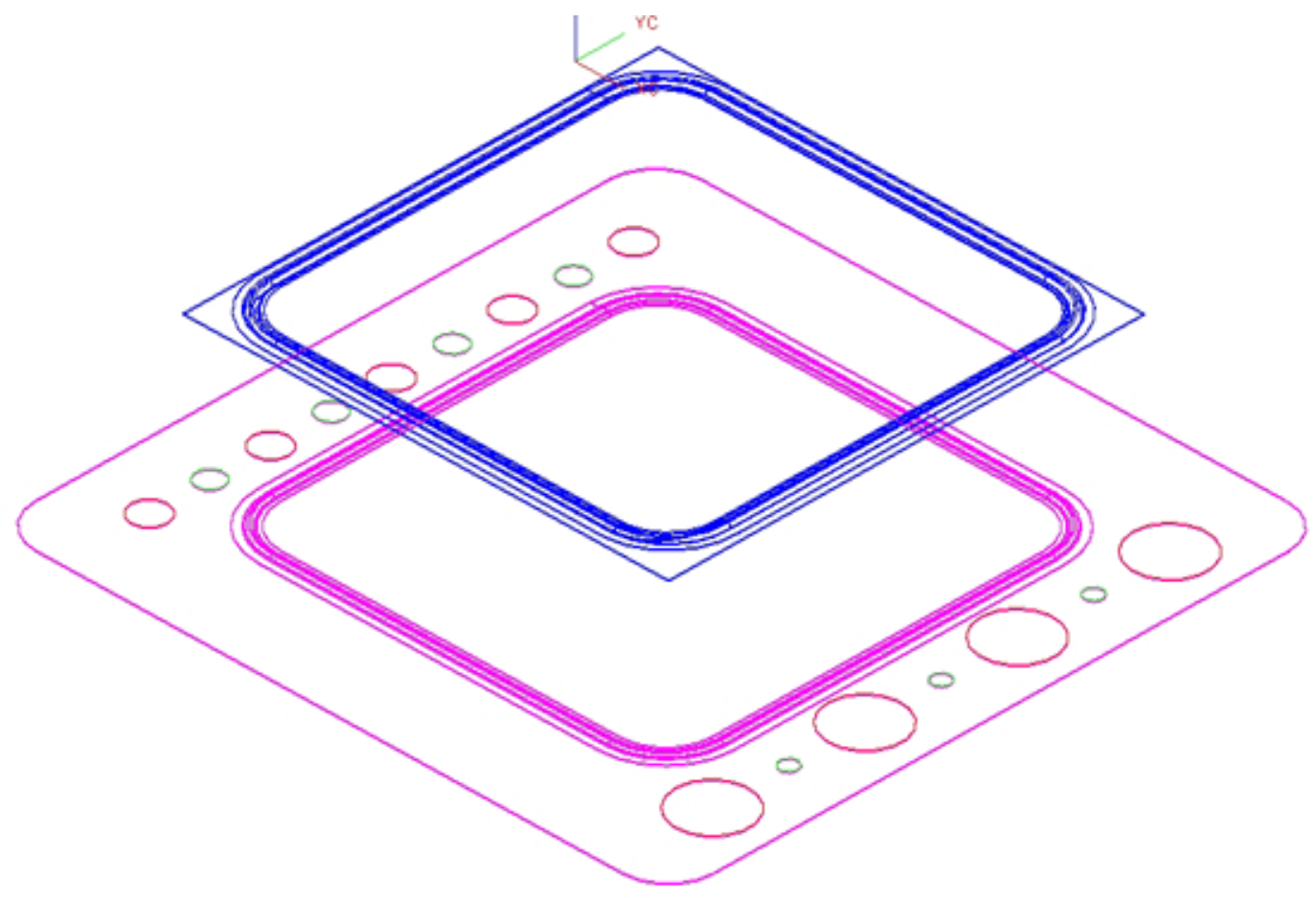

Figure 9. Insertable via interconnect design as an exploded line drawing. Outer (purple) portion is made of a ferritic stainless steel. Inner (blue) portion is made of a Ni-based superalloy.

\section{CONCLUSION}

The results of this report identify two new interconnect designs which include the material specifications. The difference between the designs is the type of sealing utilized in the SOFC stack. Stack manufacturers using bonded seals would use the double-coated, insertable-via interconnect design while stack manufacturers using compressive seals would use the doublecoated interconnect design. The double-coated interconnect is coated with strontium-doped, lanthanum cobaltite (LSC) on the cathode side and a manganese coating on the anode side of the interconnect. The interconnect substrate would be made of Haynes 230 or another Ni-based superalloy with slow oxidation kinetics at $750^{\circ} \mathrm{C}$ in air and wet hydrogen atmosphere. The double-coated, insertable-via, interconnect design would consist of a center made from Haynes 230 which is double-coated with LSC on the cathode side and manganese on the anode side. The outer part of the interconnect is made of a ferritic stainless steel and is used to attach the bonded sealing materials. The center piece is joined to the outer piece of the interconnect by a compliant braze joint which accommodates the coefficient of thermal expansion mismatch between the ferritic and nickel-based superalloy. The LSC coating was shown to retard the diffusion of chromium to the surface where it can vaporize particularly in the presence of water vapor at temperatures below $900^{\circ} \mathrm{C}$. 8,9 These interconnect designs can help to solve many of the problems associated with metallic interconnects in SOFC stack technology. 


\section{REFERENCES}

${ }^{1}$ D. England and V. Virkar, J. Electro. Chem.. Soc., 146, 9, 3196, (1999).

${ }^{2}$ D. England and V. Virkar, J. Electro. Chem. Soc, 148, 4, A330 (2001).

${ }^{3}$ Diane England, thesis, A Metallic Interconnect for a Solid Oxide Fuel Cell Stack, University of Utah, 2003.

${ }^{4}$ United States Patent No. 6,054,231.

${ }^{5}$ United States Patent application, A double-coated interconnect for SOFC stacks, authors Diane M. England, Delphi and Lane Wilson, NETL.

${ }^{6}$ United States Patent application, A double-coated, insertable via, interconnect for SOFC stacks, authors Diane M. England, Delphi and Lane Wilson, NETL.

${ }^{7}$ Fundamentals of Brazing, Kay \& Associates, Daniel Kay, 2003.

${ }^{8}$ G.C. Fryburg, F.J. Kohl and C.A. Stearns, J. Electro. Chem.. Soc., 121, 7, 952, (1974).

${ }^{9}$ D. Caplan, M. Cohen, J. Electro. Chem.. Soc., 108, 5, 438, (1961). 